\title{
LINES ABOUT CONSTITUTIONAL HEALING PROBLEM
}

\author{
NOTAS SOBRE A TEORIA DA CURA CONSTITUCIONAL
}

\section{Emerson Ademir Borges de Oliveira}

\begin{abstract}
Mestre e Doutor em Direito do Estado pela Universidade de São Paulo. Pós-Doutor em Democracia e Direitos Humanos pela Universidade de Coimbra. Professor permanente e vice-coordenador do Programa de Mestrado e Doutorado em Direito da Universidade de Marília. Advogado e parecerista.

E-mail: emerson@unimar.br
\end{abstract}

Recebido em: 24/09/2018

Aprovado em: 27/04/2020

\begin{abstract}
Can the Constitution be healed? The aim of this article is the answer on how to deal with offenses committed in the face of the Constitution which are built on consolidated factual situations. Often the simple declaration of unconstitutionality, either from the beginning, the theory of nullity, or for the future, in annulability theory, or in conjunction both with the temporal modulation effects will not show positive responses to the constitutional offense. On the other hand, the recognition of unconstitutionality, although for the future, could lead to more harmful economic, political, social and legal effects than maintaining the offensive act. Sometimes the theory of constitutionalising supervening can respond appropriately, with the change of the constitutional paradigm. But what to do when the Constitution is even changed? The methodology for the development work is eminently literature and case law.
\end{abstract}

Keywords: Constitutional healing; Annulability theory; Temporal modulation effects; Facts normative power.

RESUMO: Pode a Constituição se curar? O que persegue o presente artigo é a resposta sobre como lidar com as ofensas perpetradas em face da Constituição que se construam sobre situações fáticas consolidadas. Muitas vezes a simples declaração de inconstitucionalidade, seja desde o início, na teoria da nulidade, seja para o futuro, na teoria da anulabilidade, ou seja, em conjugação de ambos, com a modulação temporal de efeitos, não apresentará respostas positivas à ofensa constitucional. Ao contrário, o reconhecimento de inconstitucionalidade, ainda que para o futuro, poderá gerar efeitos mais danosos econômica, política, social e juridicamente do que a manutenção do ato ofensivo. Algumas vezes, a teoria da constitucionalização superveniente poderá responder adequadamente, com a mudança do paradigma constitucional. Mas o que fazer quando a Constituição sequer é alterada? A metodologia para o desenvolvimento do trabalho é eminentemente bibliográfica e jurisprudencial.

Palavras-chave: Cicatrização constitucional; Teoria da anulabilidade; Modulação temporal dos efeitos; Força normativa dos fatos. 
SUMARY: Introduction. I. The problem of the control model and the overcoming of the nullityannulability dicotomy. II. Supervening constitucionalization and constitutional healing. III. Limits and practical effects in the decision technique. Conclusion. References.

\section{INTRODUCTION}

The tough question of the nullity of constitutional law has generated deep discussions in constitutional law, in Brazil and around the world. Until a few years ago, we were insisting on the more concise idea that the unconstitutional law is born dead and has been void since its inception. Or how would you approach the maxim of the American judicial review, the inconstitutional statute is not law at all (WILLOUGHBY, 1910, p.9-10).

An idea that, in fact, goes right back to the control of Yankee constitutionality, since in the model of European constitutional jurisdiction, since the Kelsenian conception, one has opted for the idea of annulability of the laws, opposing the regime according to which the unconstitutional law should not have had any effect, even if it had acted for a long time on people's lives.

But even the judicial review system realized the time as a great enemy of the declarations of mere nullity, overlapping with the model an idea of judicial politics and fair discussion about the effects of cold declarations of no effect for years, of the unconstitutional law.

More than that, the Courts responsible for the control of constitutionality, exclusively or not, began to deal with even more problematic issues: cases in which, in spite of the unconstitutionality of the law or of the normative act, its declaration, although ex nunc, could generate more damaging effects than its maintenance, in the legal, economic, political and social field.

In this area, with undeniable contribution of the German Federal Court (Bundesverfassungsgericht), they developed other control techniques that were intended to seek in the Legislature support for overcoming the hitherto unconstitutional situation. These techniques included a declaration of unconstitutionality without annulment (Unvereinbarkeitserklärung) and the appeal to the legislator (Appellentscheidung), who preferred the more appropriate logic of still constitutional laws (noch verfassungsgemäss), viewed as a "peculiar sentence of rejection of unconstitutionality", with a preventive content, "operating in the 'preliminary field of constitutional pathology"” (MENDES, 2007, p.406).

In addition, there are situations in which unconstitutionality, not even for the future, can safeguard the relations embodied in its regime, which have, as it were, as consummated, but with powerful effects ad eternal. One of these cases among us is the leading case of Luís Eduardo Magalhães Municipality (ADI 2,240 / BA), in which the Brazilian Supreme Court had to deal with issues that lead to a rethinking of the effects of unconstitutional law, especially when the facts lead to Right, not the other way around. And especially when the Brazilian National Congress enacted Constitutional Amendment 57, of 2008, validating the Municipalities created without the constitutional guidelines.

These same questions lead us to a timid acceptance, in the first instance, of the supervenient constitutional theory, something hitherto rejected by our constitutional control model, although this theory depends on the later change of the constitutional paradigm itself. There are situations, however, that the Constitution is not even changed and, on the face of it, we still wonder if the situation would admit the stagnation of constitutional ongoing.

It is noted that it is not a matter of giving survival to the unconstitutional content, hoping that the Legislator will make the necessary corrections, but accept that the evil caused by the unconstitutional norm has already healed and the situation, before offense, is accepted by the factical consolidation, Provided, of course, that it has not clearly intended to offend the Constitution and that the effects of the declaration of unconstitutionality are socially, politically, economically or legally worse than their maintenance. 


\section{THE PROBLEM OF THE CONTROL MODEL AND THE OVERCOMING OF THE NULLITY-ANNULABILITY DICOTOMY}

As a matter of fact, Brazil adopts a mixed system of constitutionality control, but it was inaugurated by the diffuse system in 1891, adopting the method practiced in the United States of 1803. Later, in 1965, we adopted the model of European constitutional jurisdiction.

However, due to the clear influence of the first judicial review system, Brazil ended up enjoying the doctrine of nullity of the unconstitutional law, seen as something that should never have produced any legal effect, given its clear lack of reason. That is, what is born in disagreement with the Constitution, in reality, was not born.

But even the creator of the model, the Supreme Court, decided to bend to the logic that the pledge of nullity does not always adequately respond to the problems of unconstitutionality. In Linkletter v. Walker, 1965, concluded that "the Constitution neither prohibits nor requires retroactive effect". The question of retroactivity or not of the effect of res judicata would become a matter of judicial policy, and no longer a link to the declaration of nullity.

The retroactivity resulting from the ex tunc effect of the nullity would then become a matter of judicial policy, which the Supreme Court considered appropriately when called on the nullity of convictions based on the inadmissibility of evidence obtained illegally, as recognized in Mapp v. Ohio, in 1961 (MENDES, 2012, p.572-573).

As Mendes (2012, p.575-576) argues, US constitutionalist doctrine evolved from a first moment of unconstitutionality with broad, limited and retroactive effects (limited retrospectivity) to a moment of admission for overcoming prospective overruling, limited (limited prospectivity) or (pure prospect), differentiating both about the application in the concrete case and future or even for that concrete case.

The question, from the beginning, is treated differently by the Austrian model of Kelsen. In that case, the Court's function as a negative legislator is recognized, and nullity is constituted and not only declared. As we have said, for "the Verfassungsgerichtshof, the Austrian Constitutional Court, unconstitutional law is an act with legal force until its annulment" (BORGES DE OLIVEIRA, 2015, p.225).

Kelsen, the creator of the Austrian model, already emphasized in his lessons: "The decision of the constitutional court, when the application is accepted, must pronounce the annulment of the contested act in a way that appears as a consequence of the decision itself" (2007, p.177). Exceptions to the declarative effect, the actual case itself under examination, in which retroactivity can operate.

Thus, in Austrian control, "pronouncement of unconstitutionality is effective ex nunc (from the date of publication of the judgment), unless the Court establishes a deadline for the entry into force of the cassation," to occur within a maximum of eighteen months of the decision. In any case, the retroactivity is maintained for the concrete case, understanding in that characteristic all those who have the same object and are pending judgment in the Court (MENDES, 2012, p.577).

In Spanish territory, even in the absence of thematic regulation, the Constitutional Court admits the decision of unconstitutionality without declaration of nullity. Thus, for example, in STC 13/92/17, the Court recognized that serious disturbances or prejudices to collective interests, such as consolidated situations and economic or financial policies, may justify such a decision (MENDES, 2012, p.578-579).

In contrast, Portugal expressly admits in Article 282 of its Constitution that reasons of legal certainty, equity or public interest of exceptional importance justify modifying the decision so that it does not have retroactive effect. However, in Portuguese law, as Canotilho (2007, p.1018) points out, there is no room for sentences that only declare unconstitutionality, without producing a nullity effect, except for the above situation, since the official publication of the Court 
consubstantial absolute limit: "a norm can not continue to take effect after the publication of the decision declaring it unconstitutional with general binding force".

In Germany, although the prevailing view on the nullity of the law declared unconstitutional, techniques were developed to circumvent the retrospective effects of such $a$ declaration, such as the declaration of unconstitutionality without annulment (Unvereinbarkeitserklärung) and the appeal to the legislature (Appellentscheidung) ${ }^{1}$.

As Mendes (2012, p.583) points out, at the beginning of the last century, under the Weimar Constitution, Triepel argued in the Referat case that questions with a high political content, when submitted to the Court, should receive answers outside the procedural tradition, in view of the incompatibility of this in Those issues. Still, Walter Jellinek already argued that the declaration of nullity should be used only when it was sufficient to solve the problem submitted to the Reichsgericht.

The appeal to the legislator can be shown as an adequate technique precisely in cases of still constitutional laws (noch verfassungsgemäss). The technique of the Appellentscheidnung derives from the praxis of the German Federal Constitutional Court and shows, as Minister Mendes (2007, p.406) points out, as a "peculiar sentence of rejection of unconstitutionality", with a preventive content, "operating in the 'preliminary field of constitutional pathology".

In addition to operating in the pedagogical field, in order to exhort the constitutional duty to legislate, Bulos (2010, p.364) points out that the appeal to the legislator also serves to "preserve situations constituted in the face of changes in the factual and legal relations" and "to attest if there was constitutional offense".

Such content gives, in the view of the STF Minister, greater emphasis on the eternal rightpolitical binomial (MENDES, 2007, p.396), making the relationship between both intrinsic and more dependent.

In Germany, it is common to point out the decision of 4 May 1954 on the Saarland Statute (Sarrstatut) as the starting point for the construction of the appeal to the legislator. At that time, the Court stated that legislative measures taken to overcome the occupation status, although imperfect, contributed to a gradual reconciliation of the legal situation with the Grundgesetz. And for that reason they were still constitutional laws (MENDES, 2007, p.403-404).

Although this broad range of decisions has Germanic roots, and is at first incompatible with the American model, it is true that for some time the US Courts have abandoned the purely expurgatory practice of the unconstitutional rule to assume a more taxing role of positive obligations.

On the subject of democracy, the German Court understood that, as regards the division of electoral districts, the factual changes would lead to a process of unconstitutionalisation, since the principle of electoral equality was no longer being met, and refusing to declare the unconstitutionality of Legislature to make the necessary modifications to reduce the existing discrepancy to tolerable thresholds ${ }^{2}$.

At that time, on May 22, 1963, the Court faced the old problem of changing the factual reality without legislative change, and the division was based on the demographic structure of 1949. Refusing to declare the unconstitutionality, the Court Safeguarded the German democracy, avoiding the invalidity of the last elections and, consequently, the Parliament itself and the Government. And in view of the fact that the previous legislature had already closed, there would be no possibility of enacting the proper law, falling into an institutional vacuum (MENDES, 2007, p.408).

\footnotetext{
${ }^{1}$ The term was created by Judge Emmi Agathe Karola Margarete Wiltraut Rupp-von Brünneck of the German Federal Constitutional Court in a 1970 article entitled Darf das Bundesverfassungsgericht an den Gesetzgeber appellieren?

${ }^{2}$ BVerfGE: 16,130
} 
Of course, the Court could not fail to take into account that the factual change was not found at the time of enactment of the law under attack and the difficulty in identifying the issue ${ }^{3}$. Faced with the Court's conscious decision in 1964, Parliament issued a new law, adapting the electoral districts.

About the declaration of unconstitutionality without the pronouncement of nullity (Unvereinbarkeitserklärung), another technique also developed among the Germans, part of the pedagogical effect of recognizing that a particular law is unconstitutional, but, in practice, realizes that the withdrawal of unconstitutional law from the Legal system brings more harm than good. Therefore, it does not declare the nullity.

As Urbano (2016, p.112) points out, the technique was created by jurisprudence, but later positivized in 1970, in the Organic Law of the German Federal Constitutional Court. It has been applied in the following situations:

1) Regarding transitional law: the judge ignores the declaration of unconstitutionality when the legislator had no alternative, given the existing historical context;

2) When unconstitutionality is not evident, in particular, for reasons of public security;

3) When the absence of the unconstitutional norm is less adequate than the very maintenance of the constitutional norm;

4) When discriminatory disciplines are involved.

As an unorthodox solution, the above-mentioned author emphasizes that the decisionmaking technique ends up approaching vacatio legis, so that the legislator can intervene and resolve the legal vacuum. More than this, the technique departs from the most common German law sentences, with ex tunc efficacy, to take a position closer to Austrian law, ex nunc. In addition, its usefulness stems not from the suspension of the law declared unconstitutional, but from the continuity of its application, which has been exception in the decisions of the TC (URBANO, 2016, p.112-113). It is explained, there would be little in the technique if it simply suspended the law declared unconstitutional, since its effects would cease and we would fall into the legislative vacuum. Its logic stems from the provisional continuity of application, waiting for an urgent legislative solution.

In fact, these decisions, which address political rather than legal issues, elucidate the concern, since the last century, "with the danger of the pure and simple adoption, by the constitutional jurisdiction, of the forms of decision established by ordinary jurisdiction" (MENDES, 1993, p.64). In the early 1980s, the technique was already so widespread in court that it was comparable to simple nullity decisions.

It should be noted, however, that a declaration of unconstitutionality without uttering a nullity hides the risk of falling into the Court's pure will, since there are no certain parameters as to when this should occur. It is clear that legal certainty in the face of such questions can be somewhat threatened, which does not make the measure unfeasible. Rather, it recommends prudence.

In any case, the application of the law declared unconstitutional is something that finds support in the legal system itself, according to Pestalozza (1976, p.565-566). Its legitimacy stems from the Constitution itself, insofar as its suspension may lead to offenses against fundamental rights, as decided by the Court in the judgment on the nationality of children born in "mixed marriages" 4 .

\footnotetext{
${ }^{3}$ The Bundesverfassungsgericht has pointed out: "The difficulty of specifying the exact moment when the division of electoral districts, formerly legitimate, became incompatible with the Constitution, is mainly based on the fact that this development is characterized by An unstable transition period, which made it difficult for this development to be predicted, in its entirety, with the necessary security". BVerfGE: 16, $130(142 / 143)$.

${ }^{4}$ BVerfGE 37, 217.
} 
Among the Americans, in Colegrove v. Green in 1946, Judge Frankfurter understood that the constituencies, as they were divided, were unconstitutional, but the nullity decision would be worse than maintaining the division, given the fact that the State of Illinois would be without a division Valid, awaiting, finally, a solution of the legislator (O’BRIEN, 1991, p.111).

In Brazil, as known among the constitutionalists, the possibility of modulation developed from articles 27 of Law 9,868 / 99 and 11 of Law 9,882 / 99, assuming that reasons of legal certainty or exceptional public interest could justify modulation temporal effects of the declaration of unconstitutionality.

It is noted that, around the world, the dichotomy of annullability-nullity, resulting from the control system adopted, lost its meaning, especially in countries like ours that ended up adopting a mixed system of constitutionality control. Moreover, even diffuse control countries, which have always defended the nullity of the unconstitutional law, have had to deal with the reality of a useful decision, that is, one in which nullity is not recommended because its effects would be pernicious in the face of fait accompli.

\section{SUPERVENING CONSTITUTIONALIZATION AND CONSTITUTIONAL HEALING}

Among us, moreover, the Supreme Court had in question a rather tough question in which the main discussion ended up becoming precisely the effect to be conferred on the declaration of unconstitutionality. This is the Direct Action of Unconstitutionality 2,240 / BA.

This action sought to declare unconstitutional the State Law of Bahia 7,619 / 00, which created the Municipality of Luís Eduardo Magalhães ${ }^{5}$, after Constitutional Amendment 15/96, which requires the Federal Complementary Law to determine the guidelines for the creation of new municipalities, Such as the need for prior consultation, through plebiscite, of the populations involved, dissemination of Municipal Feasibility Studies and periods, according to article 18, §4, $\mathrm{CF}$, without the said state law having obeyed any of these guidelines.

However, failure to comply with the guidelines of EC 15 in the creation of the said municipality, in a traditional reading, would entail the understanding that not only its own creation would be null, but also all the municipal acts practiced since then. With the declaration, 16 years of local public acts would be torn.

The Supreme Court envisaged an exceptional hypothesis, due to its consolidation since 2000, and the nullity in the current municipal stage would entail serious risk to legal security. Worse than that: nullity, with the justification of respect for the Constitution, would imply an evil even greater than the maintenance of the state of affairs. At the time, the Supreme Court preferred to leave on the tangent, granting a period of 24 months for the legal regularization of the Municipality, under the terms of EC $15^{6}$.

\footnotetext{
5 The Municipality was founded on March 30, 2000 and, according to the 2015 Census, has a population of 79,162.

6 "1. The Municipality was effectively created and assumed existence, for more than six years, as a federative entity. 2. Existence of fact of the Municipality, resulting from the political decision that imported in its installation as federative entity endowed with autonomy. Consolidated exceptional situation, institutional, political. Hypothesis that consubstantiates recognition and acceptance of the normative force of the facts. 3 . This Court cannot be limited to the practice of mere exercise of subsumption. The situation of exception, a consolidated situation - although not yet legal - cannot be disregarded. 4. The exception results from the omission of the Legislative Power, since the impediment of creation, incorporation, merger and dismemberment of Municipalities, since the enactment of Constitutional Amendment n. 15, on September 12, 1996, is due to the absence of a federal supplementary law. 5. Omission of the National Congress that makes unfeasible what the Constitution authorizes: the creation of a Municipality. Failure to issue the supplementary law within a reasonable period would constitute an authentic violation of the constitutional order. 6. The creation of the Municipality of Luís Eduardo Magalhães imports, as it happened, an exceptional situation not foreseen by positive law. 7. The state of exception is a zone of indifference between chaos and the state of normality. It is not the exception that is subtracted from the norm, but the norm which, when suspended, gives way to

Revista de Direito Brasileira | Florianópolis, SC | v. 25 | n. 10 | p. 3-16 | Jan./Abr. 2020
} 
There was a clear choice for the consolidated situation in fact, choosing to present later the constitutional requirements as a measure to meet the requirements of the Constitution, with a view to the facts.

It happens that the constituent legislator ended up choosing the exit of the supervenient constitutionality. To understand, first, the concept, we must bear in mind that in some situations, the law is unconstitutional before the parameter - constitutional text - valid at the moment of its creation. Subsequently, there are changes in the constitutional text - or even a new Constitution and that law that was unconstitutional is no longer incompatible with the current text, "constitutionalizing."

As we have already said, in view of the adoption of the theory of nullity, by which the unconstitutional law is born dead, there would be no possibility of supervenient constitutionalisation. And our Supreme Court has always inclined accordingly ${ }^{7}$. But in view of the modulations presented and with the prerogative of annulability, it would be possible for the change of parameters to reach the law that was previously unconstitutional ${ }^{8}$, since it has not been effectively declared erga omnes.

This was the path taken by the constituent legislator with the promulgation of Constitutional Amendment 57 which included article 96 in the ADCT with the following wording: "The acts of creation, merger, incorporation and dismemberment of Municipalities, whose law has been validated, are validated. Published until December 31, 2006, meeting the requirements established in the legislation of the respective State at the time of its creation, "opposing head-on the content of EC 15 of 1996 that modified article 18, paragraph 4, of the Federal Constitution ${ }^{9}$.

It can be seen that, in the case in question, the solution is presented by supervenient constitutionalisation, but it does not deny the existence of several other elements to circumvent the hard case that would merit a dedicated analysis, other than EC 57, such as legal certainty the consolidated factual situation and objective good faith. And we call this attention because it seems to us that they are elements that must be considered in other cases when the constitutional parameter change is not present.

In other words, is it possible to save the unconstitutional law even when the Constitution is not altered to fit the norm to the parameter?

First of all, it must be stressed that this is an absolutely exceptional situation. The theory should not serve as a shield to the legislator to perpetrate deliberate offenses against the constitutional text, waiting for inertia in the future to consolidate the offense and make the acts

\footnotetext{
the exception - only in this way does it constitute a rule, remaining in relation to the exception. 8. The Federal Supreme Court decides to regulate these exceptional situations as well. He does not depart from the order, in doing so, he applies the rule to the exception by dislodging it, that is, by removing it from the exception. 9. It is necessary to verify what less compromises the future normative force of the Constitution and its function of stabilization. In the apparent conflict of unconstitutionalities it would be necessary to recognize the valid existence of the Municipality, in order to move away from aggression to the federation. 10. The principle of legal certainty is to benefit the preservation of the municipality. 11. Principle of State continuity. 12. Judgment in which the decision of this Court was considered in MI n. 725, when it is determined that, within a period of eighteen months, when the Federal supplementary law referred to in Paragraph 4 of Article 18 of the Brazilian Constitution is published, it shall be deemed to recognize the consolidated existence of the Municipality of Luís Eduardo Magalhães. Declaration of unconstitutionality of the state law without pronouncement of its nullity 13. Direct action deemed appropriate to declare unconstitutionality, but not pronounce nullity for the term of 24 months, of Law n. 7,619, dated March 30, 2000, of the State of Bahia. "Direct Action of Unconstitutionality 2,240 / BA. Rel. Min. Eros Degree. Judgment: May 8, 2007.

${ }^{7}$ RE 390.840, rel. Min. Marco Aurélio, DJ 15.08.2006.

8 "Therefore, changing the constitutional parameter, there is no longer a threat to the supremacy of the current Constitution, moving away from the possibility of exercising abstract control of constitutionality." (NOVELINO, 2011, p.155).

${ }^{9}$ Paragraph 4. The creation, incorporation, merger and dismemberment of Municipalities, shall be made by state law, within the period determined by Federal Complementary Law, and will depend on prior consultation, through plebiscite, to the populations of the Municipalities involved, after Disclosure of Municipal Feasibility Studies, presented and published in accordance with the law.
}

Revista de Direito Brasileira | Florianópolis, SC | v. 25 | n. 10 | p. 3-16 | Jan./Abr. 2020 
valid. There should not be a theory that seeks to safeguard the Constitution, in fact, if it justifies constitutional violations, serving as a refuge for unconstitutionalities.

In the judgment of ADI 2,240, in question, the Supreme Court stated that the unconstitutionality was established by the normative force of the facts, especially in view of the legislature's inertia in creating the complementary law that would regulate the creation of new Municipalities, which, by itself alone, was already presented as unconstitutional by omission. It is seen that if the law can't keep up with the facts, they will continue to walk against the law.

In addition, the factual situation was established with apparent respect for the populations involved and the political decision of municipal creation and maintenance or, as Jellinek (2000, p.319) would say, from the normative force of facts (normative Kraft des Faktischen), that is, "what allows Understand the origin and existence of the legal order, for in the life of the State real relations precede the norms in function of them produced" (VIEIRA; BRASIL, 2007, p.306-307).

Next, it should be pointed out that, although in the public domain, the analysis of unconstitutionality deserves the eyes of objective good faith or, in Larenz's (2001, p.91) view, of trust, emphasizing that the legal order is an ethical principle, in That people should be faithful to their purposes and straightforward in the confidence they had once held ${ }^{10}$. In the same way, the State must behave. If the situation was consolidated under the eyes of the public entity itself, it would not be necessary, later, to claim the impossibility of constitutional correction.

Thus, it seems to us that constitutional healing can be offered as a response to exceptional situations that, based on state trust, ethical principle and consolidation of facts, recommend the natural healing of the Constitution, as the formality to the letter will still have unfortunate impacts greater.

\section{LIMITS AND PRACTICAL EFFECTS IN THE DECISION TECHNIQUE}

It is clear that constitutional healing as a material prerequisite for maintaining a consolidated factual situation cannot serve as a shield for abuses under the Constitution. Otherwise, any violation of the rule, however serious, could protect itself in theory from being remedied. This act would clearly be an affront to the constitutional text and to the popular will that lends it.

Respecting the Constitution is the first assumption of constitutionalism.

Every Constitution brings in itself not only the factual reality of a people, but also their yearnings for a future sometimes not so close. And he would not even have to name such Constitutions as leaders or programmers, as Canotilho (2007, p.217-218) would do in dealing with the norms and end-rules of the Portuguese Constitution of 1976.

So much so, that such Constitutions would be compromised because they were part of a pluralistic and complex society, expressing agreements that were fruit of convergence, agreements and existing factual differences.

Indeed, it is the nature of every fundamental law to reflect the social-economic aspect of a people embedded in a particular territory, chiefly in terms of its material meaning ${ }^{11}$, without losing sight of the objectives and implementation of certain programs for the benefit of that people.

This conceptualization is very close to that predicted by Bäulin, for whom the Constitution is at one time fundamental order and program of action:

\footnotetext{
10 "The defense of fidelity and the maintenance of trust form the foundation of legal traffic and especially of special legal relationships. The principle (of good faith) is therefore not limited to compulsory legal relationships, but applies according to a now peaceful view, as a general principle of law, applicable wherever it exists or is prepared in the special legal relationship. Faced with these requirements, so also in the Law of Things, in Civil Procedure and in Public Law." (LARENZ, 1987, p.127).

${ }^{11}$ On Formal and Material Constitution, see: KELSEN, 2000, p. 182-183.
}

Revista de Direito Brasileira | Florianópolis, SC | v. 25 | n. 10 | p. 3-16 | Jan./Abr. 2020 
In addition to being the basic law of the State (legal perspective), the Constitution is also the fundamental ordering and shaping of social life (sociopolitical perspective), within which the most significant global social ends are formulated, where tasks of the community and where, after all, the political process is ordered as a whole (MENDES; COELHO; BRANCO, 2008, p.8).

In addition, according to Miranda (2011, p.210), what inaugurates a new constitutional era is not the approval of a formal constitution, but rather "the cut or the opposition to the situation or to the regime that hitherto was in force, in the name of a new idea of law or of a new principle of legitimacy, whether through revolution or otherwise".

The Portuguese constitutionalist also recalls that the material constituent power precedes the formal because the idea of Law comes before the rule of Law, "value commands the norm, fundamental political option the form that elects to act on the facts, legitimacy the legality" (MIRANDA, 2010, p.212).

In one of the classic concepts of Constitution, Ferdinand Lassale emphasizes that the true Constitution of the country must reflect the "real and effective factors of power" and such written Constitutions have no value and do not last if they are not faithful expressions of the factors of power that prevail in Social reality (LASSALE, 1931) ${ }^{12}$.

But it is well to bear in mind that the Constitution neither shapes nor embodies reality. On the one hand, no law has the power to alter human pretensions by itself. On the other hand, and therefore the Constitution must contain essentially constitutional norms, the world does not end in the constitutionally designed model.

The Constitution is a project in that, among one of its purposes, lies in itself the materialization of the rights it ensures, because they are fruits of the sovereign yearnings of the people. Without the effectiveness of the rights it promises there is no reason at all for its existence. That is, there is natural loss of purpose. In this sense, Grau (1985, p.46): "All its precepts will have immediate efficacy and application, behold, only in this way will it cease to play the role of deception and illusion of the people". Or, according to Hesse (1991, p.16): "The Constitution acquires normative force in the measure in which it manages to realize this pretension of effectiveness".

And precisely because it deals with questions that are substantially derived from the popular yearnings, it could be said that the implementation of the Constitution is, to a certain extent, the celebration of the democratic plan.

In addition, it should be noted that the "constitution is a prominent law that conforms the State" (CANOTILHO, 2007, p.89). With these words, Canotilho concludes that the Constitution can only be understood from the State, conferring, in the terms of the Hegelian philosophy and the German public policy, order to it.

The master of Coimbra, developing the theme of the hierarchical-normative position superior of the Constitution, emphasizes that, excepting some questions of the community law, there are three expressions on the subject.

In the first place, the Constitution is endowed with normative self-primacy, because constitutional norms constitute a higher law that recognizes "the foundation of validity in itself." That is to say, it does not depend on recognition of another norm, it being enough, in the words of the Portuguese professor, that it be endowed with "democratically made and accepted norms (democratic procedural legitimacy) and informed by 'basic structures of justice' (material legitimacy)" (CANOTILHO, 2007, p.1147-1148).

\footnotetext{
${ }^{12}$ Still, the lesson of Miranda (2010, p.32): "In the Constitution a certain system of values of public life is formed, of which it is then inseparable. A set of philosophical-juridical and philosophical-political principles (albeit from somewhat different inspirations) comes to justify and comes to create".
}

Revista de Direito Brasileira | Florianópolis, SC | v. 25 | n. 10 | p. 3-16 | Jan./Abr. 2020 
Second, "the norms of the constitution are standards of norms", being source of juridical production of infraconstitutional norms (CANOTILHO, 2007, p.1148-1149). This process, formally and materially in the Constitution, that is, not only in the way the laws are drafted, but also in determining the substantial limits of each normative species (see, for example, our article 146, ensuring that it is reserved to the complementary law tax issues). Of course, as far as constitutionality control is concerned, all these issues are summarized in the legal formalities, regarding the alignment of the law with the Constitution. That is to say, even if the norm exceeds its material limit (ex: Ordinary Law disposing on tax prescription), the unconstitutionality will be formal, due to incompatibility between the norm and the norms norm.

Third, because the constitutional rules are in a topological position superior, the acts of the public powers must be in conformity with the Constitution. In the aspect of negative determinant, the Constitution presents as limit to the inferior norms. As regards the aspect of positive determinant, the constitutional norms conform the lower legislation (CANOTILHO, 2007, p.1149). This point, moreover, can be especially visualized in Brazil in the conformation of the Civil Code of 2002 to the Constitution and, more recently, in the principles that guided the structuring of the New Code of Civil Procedure ${ }^{13}$.

Hence it is unmistakably seen that the use of healing to legitimize constitutional violations per se would be a violation in and of itself. More than that: a violation of the will of the people, the constitutional project, the constitutional programs and the legal system as a whole, as seen above.

What, then, are the situations that would indicate the use of the theory and the limits for its application?

Firstly, it must be borne in mind that healing cannot operate on what is classified by Schmitt (2001, p.47) as eminently constitutional matter, that is, the fundamental political decision, the structuring norms of a State, that give it confection and identify the power of the originating constituent power.

In other words, the fundamental norms of the State cannot be beaten and accepted by healing, under penalty of subversion of the original constituent power. Thus, fundamental principles, fundamental rights and the organization of the State and of the Powers never admit any possibility of cure in the face of vices of unconstitutionality.

Secondly, scarring should be a lesser evil in the face of nullity. That is, the effects of the declaration of nullity must be more pernicious than the maintenance of the own unconstitutionality. That is the case, cited above, of the nationality of children born of "mixed marriages" in German case law. In the same way, the maintenance of the electoral districts mistakenly divided.

Thirdly, the situation must be consolidated by the facts. A recent unconstitutionality does not admit the exception. It is necessary that a whole juridical situation has been erected on the unconstitutionality proposed, in a way that would undermine the security and the good faith of the people the declaration of nullity, as had happened with the Brazilian Municipality of Luís Eduardo Magalhães.

Finally, it is imperative that we keep in mind that this is a very exceptional situation, under penalty of transforming the Constitutional Court into a clear constituent legislator.

In technical terms, two would be the proposed outputs for decisions that, taking into account the above elements, resolve to materialize healing: a) declaration of past unconstitutionality without producing effects; B) declaration of unconstitutionality past with appeal to the legislator for future correction.

Both work with the same assumption: the declaration of unconstitutionality in the past. That is, they recognize that the situation, when operated, really was offensive to the constitutional text. But they return this statement to the last moment, in which the violation began. This means

\footnotetext{
${ }^{13}$ Especially interesting is Article 1 of the aforementioned procedural law: "Civil proceedings shall be ordered, disciplined and interpreted in accordance with the fundamental values and principles established in the Constitution of the Federative Republic of Brazil, in compliance with the provisions of this Code."
} 
that only the unconstitutionality of the past is recognized, but not the present one, which has followed in continuity with that operated in the past. It is during this time that healing occurs. The situation that was previously unconstitutional, and even so recognized, ceased to be so, without the need for any change in the constitutional parameter. The healing, so to speak, operates in the middle, between the moment of founding unconstitutionality and the moment of the Court's decision.

What differs from the two techniques is the need for correction or its dispensation, due to low constitutional offensiveness and the possibility of nonconflict interpretation based on other constitutional principles. On the one hand, the situation itself is already remedied by healing. On the other, it also healed, but it would be more appropriate to operate supervenient constitucionalisation, altering the constitutional text.

The declaration of unconstitutionality without effects has the purpose of simply recognizing that time has healed the constitutional wound. What was unconstitutional became a consolidated fact, no longer offending the norm. And, being of low lesivity, in addition to being possible to resort to the principles of the Constitution itself to conclude according to what was before offense, no legislative act is recommended. It is enough that the decision recognizes the past fact, but has no effect.

On the other hand, the declaration of unconstitutionality of the past, with an appeal to the legislator for future correction, although this healing also operates, recognizing the non-continuity of the injury to the Constitution, in view of the assets and depth of the offense, recommends that, for the future, The constitutional text to consolidated reality, in order to give more legal security to those involved. It does not produce any nullity effect, but only the pedagogical character of the decision to warn the reforming constituent that it would be more appropriate to change the Constitution. If this happens, then we will have a hypothesis of supervenient constitutionalization. The difference is that the unconstitutionality of the norm without nullity had already been recognized.

Both models, supported by the protection of the constitutional core, should be guided by the limits of healing. And in both cases there is a recognition that time can heal even the Constitution.

\section{CONCLUSION}

We began our text with the question about the healing of the Constitution violated by acts of offense to its text. First of all, we want to know if time can close the wounds of the Constitution without it being at least modified.

It is that in situations where the parameter is altered, as we have seen, the theory of supervenient constitutionalization can offer good answers to the phenomenon, accepting that, due to annulability, the law not yet declared unconstitutional remains intact and already under the new parameter can no longer receive the chaste of unconstitutionality.

The understanding of the answer to questioning goes through the untying of our mixed model of the theory of nullity, widely accepted but already excepted among us. As we have seen, even the judicial review model has tended to the possibility that unconstitutionality cannot be solved simply by nullity.

Moreover, the analysis of unconstitutional law invariably carries us to the path of the factual and political context of the situation. Not that the facts can always justify unconstitutional conduct. And, in fact, the proposed healing is extremely exceptional. But it must be admitted that, in the face of trust and good faith, the consolidated factual situation and the normative force of the facts may rethink the mere declaration of unconstitutionality. 
It's always good to emphasize the idea of Miranda (2010, p.212), for whom "the idea of law precedes the rule of law, value commands the norm, the fundamental political option the form that elects to act on the facts, legitimacy legality".

Even in the face of questions not answered by the change of constitutional parameter supervenient constitutionalization - the interpreter should not surrender to the simplistic seduction of nullity. At times, the people themselves, who so much offer to the original constituent power, do not intend to bend to nullity, accepting the path that will bring them the least harm.

Given this, we accept the proposed idea, but not for any part of the constitutional text. Certain limits must be imposed so that healing does not end up frustrating the constitutional project.

In view of this, healing has the following restrictions: a) it cannot occur in the face of fundamental norms of the Constitution, such as fundamental principles, fundamental rights and organization of the State and the Powers; B) healing should be a useful evil, a lesser evil than the declaration of nullity. In other words, there must be proportionality in the decision that decides not to determine the nullity; $\mathrm{C}$ ) the unconstitutional situation must be consolidated by the facts, so that nullity would offend legal certainty and good faith; D) healing can only occur in very exceptional situations.

With regard to the decision-making techniques proposed for the implementation of constitutional healing, we present: a) declaration of past unconstitutionality without producing effects; B) declaration of unconstitutionality past with appeal to the legislator for future correction.

In the first, it is recognized that the situation was unconstitutional, but that, at the moment of the decision, it is no longer, and the cicatrization takes place in time. In view of the low constitutional offensiveness and the possibility of nonconflict interpretation based on other constitutional principles, no activity other than a declaration of unconstitutionality is recommended. The facts, by themselves, have already made the situation constitutional and even legally consolidated.

In the second, the assumption is the same. What changes is that, in view of the offense and the depth of the offense, although there has been healing, it is recommended that the constituent legislator align the constitutional text to the consolidated situation, which, if it occurs, will institute supervenient constitutionalisation.

In any case, it should be emphasized that healing situations, by allowing time to deal with constitutional injuries, must always be governed by the idea that the judiciary should not be transformed into a legitimator of offenses against the Constitution, but a body that in the face of life and dignity, folds to the material constitution, to recognize that the facts can change the Law.

\section{REFERENCES}

BORGES DE OLIVEIRA, Emerson Ademir. Ativismo judicial e controle de constitucionalidade: impactos e efeitos na evolução da democracia. Curitiba: Juruá, 2015.

BULOS, Uadi Lâmego. Curso de direito constitucional. 5.ed. São Paulo: Saraiva, 2010.

CANOTILHO, J. J. Gomes. Direito Constitucional e Teoria da Constituição. 7.e.d. Coimbra: Almedina, 2007.

GRAU, Eros Roberto. A constituinte e a constituição que teremos. São Paulo: Revista dos Tribunais, 1985.

HESSE, Konrad. A força normativa da Constituição. Porto Alegre: Sérgio Antonio Fabris Editor, 1991. 
JELLINEK, Georg. Teoria General del Estado. 2.ed. México: Fondo de Cultura Econômica, 2000.

KELSEN, Hans. Jurisdição constitucional. 2. ed. São Paulo: Martins Fontes, 2007. . Teoria geral do Direito e do Estado. São Paulo: Martins Fontes, 2000.

LARENZ, Karl. Derecho Justo: Fundamentos de Etica Juridica. Madrid: Civitas, 2001. Lehrbuch des Schuldrechts. München: Verlag C. H. Beck, 1987. Band I: Allgemeiner Teil.

LASSALE, Ferdinand. ¿Qué es una Constitucion? Madrid: Editorial Cenit, 1931.

MENDES, Gilmar Ferreira. A declaração de inconstitucionalidade sem a pronúncia da nulidade da lei - "Unvereinbarkitser Klärung" - na jurisprudência da Corte Constitucional Federal Alemã. Revista de Informação Legislativa, Brasília, a. 30, n.118, abr./jun. 1993, p.61-84.

. Controle abstrato de constitucionalidade: ADI, ADC e ADO: comentários à Lei n. 9.868/99. São Paulo: Saraiva, 2012.

. Direitos fundamentais e controle de constitucionalidade. 3. ed. São Paulo: Saraiva, 2007.

; COELHO, Inocêncio Mártires; BRANCO, Paulo Gustavo Gonet. Curso de Direito Constitucional. 3.ed. São Paulo: Saraiva, 2008.

MIRANDA, Jorge. Teoria do Estado e da Constituição. 3.ed. Rio de Janeiro: Forense, 2011.

NOVELINO, Marcelo. Direito Constitucional. 5.ed. Rio de Janeiro: Forense; São Paulo: Método, 2011.

O’BRIEN, David M. Constitutional Law and Politics. New York: W. W. Norton, 1991. v. 2: Civil Rights and Civil Liberties.

PESTALOZZA, Christian. Noch verfassungsmässige. In: STARCK, Christian (Hrsg.) Bundesverfassungsgericht und Grundgesetz: Festgabe aus Anlaß des 25jährigen Bestehens des Bundesverfassungsgerichtes. Tübingen: Mohr, 1976, v. I.

SCHMITT, Carl. Teoría de la Constitución. Madrid: Alianza Editorial, 2001.

URBANO, Maria Benedita. Curso de Justiça Constitucional: evolução histórica e modelos do controlo de constitucionalidade. 2.ed. Coimbra: Almedina, 2016. 
VIEIRA, José Ribas; BRASIL, Deilton Ribeiro. A força normativa dos fatos como ferramenta do ativismo judicial utilizada para alargamento da competência do Supremo Tribunal Federal após a EC 45/04. Verba Juris, a.6, n.6, jan./dez. 2007, p.301-321.

WILLOUGHBY, Westel Woodbury. The constitutional law of the United States. New York: Baker, Voorhis, 1910. v. 1. 